\title{
RELATION OF PLANNING AND ZONING TO HOUSING POLICY AND LAW
}

\section{Shirley Adelson Siegel*}

Zoning will shortly celebrate its fortieth birthday in the United States. It has had a proud career, having gained acceptance by literally thousands of communities as an indispensable tool for assuring an orderly physical pattern of growth. Zoning is solidly established as a tool par excellence of the planners, and even the antiplanners-except for some diehards in Texas-find it an alluring insurance for the stabilization of property values.

But it is equally true that particularly since World War II zoning has been undergoing agonizing reappraisals from coast to coast. It has been tested and sometimes found wanting-even obsolete (a favorite characterization today of the early form of zoning ordinance, such as the uniform ordinance widely disseminated by the Department of Commerce in the 'twenties, still in use in many cities).

The adequacy of zoning regulations can be most appropriately tested against the needs of a modern housing program. Zoning is called upon to serve many programs such as schools, hospitals, industry, and transportation. But no program has objectives more complementary to those of zoning than does the housing and redevelopment program, here called housing for short. Zoning and housing alike are dedicated to improvement of our homes and neighborhoods. What other purpose than a housing one can you find in the traditional zoning restrictions on the intrusion of offensive uses into residential districts, in zoning controls to keep down crowding of the land, and in controls to assure light and air? ${ }^{1}$

The following discussion puts a spotlight on the actual relations between the housing program and the zoning ordinance. ${ }^{2}$ It is written largely from the point of view of a city housing authority, and tries to take a clinical view of the frictions, contradictions, and non-meeting of minds that are experienced in this relationship, without, however, minimizing the many successful adjustments that have been made.

What does a housing authority want from zoning? In analyzing these needs we shall find our yardsticks for measuring the adequacy of the zoning ordinance. First, a housing program seeks protection. Like any property owner, it wants protection against inharmonious uses in its area; it particularly wants proper zoning of all the

- A.B. I937, Barnard College; LL.B. r941, Yale Law School. Member of the New York and California bars. Author, Real Property Law and Mass Housing Needs, I2 LAw \& ConTEMP. ProB. 30 (I947), and other articles. Former Executive Director of Citizens' Housing and Planning Council of New York and of Los Angeles Citizens' Housing Council; now engaged in private law practice.

${ }^{1}$ A convenient compilation of the stated objectives and other provisions of zoning laws is provided by Housing and Home finance Agency, Office of the Administrator, Division of Law, Comparative Digest of Municipal and County Zoning Enabling Statutes as of October 3i, i952 (i953).

${ }^{2}$ I am indebted to Norman Williams, Jr., Director, Division of Planning, Department of City Planning, New York City, for his help in the planning and execution of this article, for which I am deeply grateful. 
area surrounding the project. Number two is the matter of sites. The housing program wants sites that are well situated from the standpoint of its own program, and zoned for the building of multiple dwellings, which is generally the only kind of housing that a public authority can afford to build. Third, the housing program demands a reasonable freedom of design. The zoning restrictions should not hamper the freedom of the authority to design with economy, variety, and good sense. Fourth, the zoning ordinance should allow the proximity of needed community and shopping facilities. And finally, as number five, the housing authority wants workable zoning procedures and a smooth and compatible relationship with the members of the city government administering the zoning ordinance and having specifically the power to grant adjustments.

To give our study a practical footing, we devised a questionnaire which we hoped would bring out the points of comfort as well as of friction and circulated it among the housing authorities of the 50 largest cities in the United States. Replies came in from over half of these authorities, ${ }^{3}$ providing a rich body of material on their experiences with zoning. The following discussion is to a large extent conditioned by these replies.

\section{Protection}

There was wide acclaim in the responses to the questionnaire over the virtue of zoning in giving protection to housing projects against unfavorable uses of the surrounding property. This judgment was volunteered in answer to a catch-all question which read as follows:

In what other ways does the zoning ordinance help or hinder your housing program?

One authority after another echoed the specific comment that zoning gave protection: "protects residential use from adverse neighborhood influences"; "helps the housing program ... same . . . benefits which accrue to other members of the community"; "helps protect our projects by controlling surrounding uses. ... Our estates are protected by zoning in same manner and extent as private housing is protected"; "helps the program in that it tends to stabilize a residential pattern in a given area and it provides protection to appropriate residential uses."

As will be noted more fully under $V$, the zoning of areas adjacent to a housing project subsidized by the Federal Government and, in some jurisdictions, the state government, is negotiated as a matter of high-level policy between the public officials involved.

Notwithstanding the wide acclaim, instances of inadequate protection from zoning were cited by certain housing authorities. The question in point was worded as follows:

\footnotetext{
${ }^{3}$ Replies were received from: New York City, Philadelphia, Detroit, Cleveland, St. Louis, Washington, D. C., San Francisco, Milwaukee, New Orleans, Cincinnati, Seattle, Kansas City, Mo., Newark, Dallas, Denver, Oakland, Columbus, Louisville, Birmingham, St. Paul, Jersey City, Fort Worth, Akron, Miami, Dayton, Syracuse, Worcester, Hartford, and Nashville.
} 
What problems, if any, has your program experienced because of obnoxious uses permitted in nearby commercial or industrial districts?

Unfavorable response tended to be mild, such as: "some"; "a few minor ones"; "some spot zoning near to projects for commercial uses which are a nuisance." One authority made articulate reference to the "usual established commercial or industrial uses in vicinity of slum clearance sites in central district of city." Another authority complained of obnoxious uses in the area, "principally railroads."

Of course, it is only fair to observe that where spot zoning takes place to permit the building of a housing project in an area zoned for industry, as an inevitable consequence of such abuse the housing project is surrounded by obnoxious uses which zoning may be powerless to prevent or control. Bitter examples can be given of this condition.

A specialized question about the effect of street widening, where made necessary by zoning requirements, in bringing heavy traffic through the project and thereby endangering small children netted one illustration. The housing project involved is adjacent to an industrial area, which accentuated the problem. The question referred to read as follows:

As to cities where the zoning ordinance restricts the height of buildings in relation to the width of the adjacent streets: have you had to widen streets in and/or around housing projects to fulfill this requirement? In your opinion, have wide streets retained or effected to comply with the zoning ordinance brought undesirable traffic through the housing project?

\section{II}

\section{SiTes}

The problem of sites is difficult enough for a housing authority quite apart from any zoning obstacles. The following is by no means an exhaustive list of the considerations that can and often do complicate the matter of site selection for a housing program:

I. The lack of vacant land. This may be aggravated by topographical conditions, as in the case of a city that is surrounded by hills or water; or by tightly drawn city limits coupled with inadequate or no extraterritorial authority to build on land beyond those boundaries. When there is no vacant land the housing authority is limited to clearance areas, where it is sorely pressed by the problem of relocating families occupying the property. The chronic shortage of houses for low-income families, who are the usual inhabitants of such areas, makes relocation one of the most difficult problems in housing.

2. Resistance to public housing. Such resistance is often based on one or more of the following grounds: the public housing project will bring low-income families into the area; it may bring in racial or national groups that are not regarded as compatible with the groups then dominant; ${ }^{3 a}$ and public housing may increase the density of the population per acre and introduce high-rise buildings.

3a See Charles Abrams, Forbidden Neighbors (r955). 
3. Location from the standpoint of transportation, work, schools, recreational facilities, shopping, and so on. As a public program, housing has to be sensitive to the interests of its tenants in being well located, to the problem of overtaxing or, conversely, making an inefficient use of, existing facilities, and to the public cost of building new ones.

4. Political pressure. The political pressure most often encountered is the pressure to allocate housing to particular political districts without regard to over-all needs or to a genuine right to priority of consideration. There are other kinds of political pressure as well. For example, in one community the site selected for public housing was the site of a notorious slum, so as to dramatize for political purposes the relationship between slum clearance and the public housing program. However, the property was in the heart of an industrial district and the selection was considered extremely unwise from a planning point of view.

5. Housing as a buffer. Sizable public housing projects have been used deliberately to create a buffer-sometimes between a residential and industrial area, and sometimes between different-class residential areas.

6. Preservation of an existing integrated racial pattern. Reference is made here to deliberate policy on the part of an authority that subscribes to the principle of racially integrated projects, but feels that it will do better to build them in borderline areas where there is already some mixed living rather than to venture into a racially pure area, where its pattern would be experimental. Such an authority will seek to use such transition or borderline areas as sites for its projects, and its racially integrated communities simply conform to the previously existing pattern. Politically the authority may have no choice if, for example, its projects are barred from the "lilywhite" districts.

7. Land costs. Comparative costs, not only of sites but also of site development, are of crucial importance to the housing authority. Some authorities report that the central sites, however desirable from many points of view, have prohibitive land values and are therefore not considered for public housing. On the other hand, another authority writes: "Economics preclude the selection of vacant land sites where utilities are lacking and must be provided for development." At least one authority is building its next housing projects on cheap marginal industrial land, which it finds the most attractive from the standpoint of cost.

The above list, while not exhaustive, may serve to suggest the many thorny problems that beset a housing authority which is looking for sites. Zoning, as the representative on earth of planning, so to speak, has the two-fold role of preventing solutions which would be poor planning, and of allowing solutions which would be good planning. A well-drafted and administered zoning ordinance might prevent the selection of a site that in the long run proves to be a poor choice for the housing program, whatever the immediate political or social objective. It may be that a great deal of the spot zoning-i.e., piecemeal amendment of the zoning regulations-done for the accommodation of housing authorities, has been poor planning; housing 
authorities would not be the best parties to consult on an issue of this kind and so the question has fallen outside the scope of our research. Indeed, under present circumstances, with little comprehensive planning done anywhere in the country, zoning ordinances cannot either be a very reliable index to "good" planning!"

Whether zoning in practice allows solutions which represent good planning (which at this time we can only interpret to mean the necessities of the housing program), without putting frivolous obstacles in the way, we attempted to test in the questionnaire by three different kinds of questions on the selection of sites: first, relating to the zoning of vacant land; second, relating to the zoning of clearance sites; and third, relating to instances in which zoning has been used as a tool deliberately to deter the siting of a housing project.

\section{A. Vacant Land}

The related item in the questionnaire to housing authorities was worded as follows:

Do you have difficulty finding vacant land sites zoned for the building types you wish to use for your projects? Is there any usual pattern observable in the zoning of outlying land, and if yes, what is it?

The suspicion that many communities in the United States have been underzoned for multiple housing, and have been putting a burden on their lower income groups by zoning their vacant land (primarily outlying vacant land) for one and two-family houses, is borne out by reading the answers to these questions. While not all housing authorities complain that they have difficulty finding vacant land sites because vacant land is not zoned for multiple housing-the only kind of housing a public program can afford to build - enough do to show that a serious problem exists. For example, one city answers affirmatively: "Yes. Extreme outer limits single family residence, followed by an inner band of two-family residence." Another says: "Yes. Usually such land is zoned for one or two-family use." Still another sizable community says: "Yes. Primarily single family residential." Another, somewhat more fully: "Yes. Although there is still considerable vacant land available in the city, it is primarily zoned as ' $\mathrm{A}$ ' residence [that is, one-family] and requires rezoning to ' $C$ ' residence for public housing project use" (that is, a zoning district in which dwelling units housing three or more families are permitted). And the difficulty in one community is that the outlying vacant land is zoned for industrial use only.

Occasionally there is a contrary note, as follows: "Outlying vacant sites can eco-

' State planning laws often specifically authorize, and sometimes direct, that local planning commissions prepare a map showing the blighted and slum areas in the community and/or that they make recommendations on both the extent and the location of public housing projects. Consult Housing AND Home Finance Agenct, Office of the Administrator, Division of Law, Comparative Digest of the Principal Provisions of State Planning Laws Relating to Housing Slum Clearance and RedevelopMENT AS OF JANUARY I, I95I (1952), and see, e.g., references to California, Connecticut, District of Columbia, Georgia, Louisiana, and New York. See also, Haar, The Master Plan: An Impermanent Constitution, supra pp. $353-4 \times 8$, this symposium. In 26 states there was no express statutory authority of any kind for the final approval or adoption of a comprehensive plan by the local legislative body. Housing and Home Finance Agency, op. cit. supra, at ii. 
nomically be planned to conform with density etc. requirements of existing zoning ordinance," citing a I952 project.

A special problem arose in one city where in certain one- and two-family districts the authority may be permitted to build "a group of not more than three single family dwellings so designed as to give the appearance of a single building. . .." The housing authority is forced into these zoning districts because of the lack of alternatives, and finds such 3-part dwellings far more costly than row houses would be. Accordingly, the authority is building more densely than it would normally build, and is being forced by the zoning regulations into an undesirable pattern of very high land coverage.

These responses on the difficulty of finding vacant land sites zoned for multiple housing call to mind the wave of cases in the law courts following World War II which upheld variances as well as spot zoning and other amendments of zoning ordinances to permit a change from one-family housing to garden apartments. Such changes were upheld in the public interest because of the housing shortage. ${ }^{5}$ These responses also call to mind the issue squarely raised in such cases as the Wayne Township case in New Jersey, ${ }^{6}$ involving the attempts of communities, usually suburban communities, to use zoning to discourage colonizing by lower income families. These objectives are often sought through minimum floor area or minimum cubic footage requirements which go beyond the necessities of decent housing standards. Such policies, compounded of school-tax worries and snobbism, are receiving some well-aimed criticism but the courts appear to be equivocating. ${ }^{7}$

The particular member of this family of problems with which we are immediately concerned-namely, the underzoning of a metropolitan area for multiple housing by an excessive zoning of vacant land for single or two-family dwellingsis clearly poor planning which will, until remedied, seriously hamper and distort the public housing program. It reveals a need for a thoroughgoing study of the city's population, their income and housing, resulting in a more enlightened zoning of the city's residential areas.

\section{B. Clearance Sites}

The housing authorities participating in the poll were asked:

Do you have difficulty finding clearance sites which are zoned for the building types you wish to use for your projects? If yes, please explain.

Difficulties have been encountered because of the zoning of clearance areas, complicating the housing authority's hunt for sites. A frequent complaint is that the "de-

"Cases cited in Comment, The Effect of the Housing Shortage on the Single-Family Residential Zone, 46 ILl. L. Rev. 745 (I95I); and Housing and HoMe Finance Agencr, op. cit. supra note 1 , at xii.

${ }^{6}$ Lionshead Lake v. Wayne Township, ro N.J. 165, 89 A.2d 693 (1952), writ of appeal dismissed, 344 U.S. 919 (1953), discussed in Haar, Wayne Township: Zoning for Whom?-In Brief Reply, 67 HARv. L. REv. 986 (r954).

${ }^{7}$ See article by Norman Williams, Jr., in companion issue of this symposium, Planning Law and Democtatic Living, 20 Law \& Contemp. Prob. 317 (1955); Housing and Home Finance Agency, op. cit. supra note $x$, at xiii. 
sirable areas generally are zoned for industrial or commercial use." In another city there was a large amount of spot commercial and industrial zoning in the central city residential areas, "which makes it difficult to find small central city sites suitable for public housing." Reported elsewhere was some difficulty in finding clearance sites which permitted the height that was contemplated for a redevelopment project.

The companion question

Is there an official master plan showing areas suitable for clearance?

elicited some comment that such plans existed or were in preparation. It appeared that the map could be and was amended, however, on application of the authoritya process analogous to spot zoning which has the potentiality of destroying altogether the usefulness of the map.

\section{Zoning to Deter Public Housing}

Difficulties of the housing authorities in finding vacant land sites or clearance sites zoned for the building type that they wish to build are often not insuperable, as will appear from the discussion of administrative compatibility below in Section V. Sometimes zoning is far from accommodating to the housing authority, however. For example, one of the questions to the authorities read as follows:

Can you recall any instance in which zoning changes were enacted clearly to prevent or deter your program in a particular area? If yes, please explain.

We did not seriously expect to draw out any examples on a cold questionnaire, although personally convinced that zoning has been used as a barricade from time to time by the enemies of the public housing program. One housing authority did reply in the affirmative, however: "County Zoning Board zoned property for industrial use." It was explained that the city had extraterritorial powers, which it used because of the dearth of sites within city limits, and thus was obliged to deal with the unfriendly County Zoning Board. Another community cited the example of a housing project which was warmly opposed on "political and racial" grounds; "zoning was not actually the issue." The hearing on the zoning change became the occasion for protest by a thousand visitors to the city hall. But the City Council voted the zoning change over the opposition, and the project is now built and occupied.

\section{III}

\section{DESIGN}

In matters of design the early form of zoning ordinance seems to be irreconcilable with the needs of modern large-scale housing projects. Architectural progress has rendered obsolete many of the traditional zoning restrictions. We are now witnessing a trend to eliminate the old style of detailed court and yard restrictions in favor of more flexible bulk controls, a trend which is resulting in the adoption of new ordinances in most of the large cities in the country. 
Dramatic illustrations of the conflict between old zoning and new housing as it is seen today in New York City are given by William Charney Vladeck in an article in the companion issue of this symposium. ${ }^{8}$ There he considers "the difficulties of applying zoning ordinances based upon the individual lot concept to large scale developments of full blocks or superblocks, surrounded on all sides by public streets and with no actual side or rear property lines...." One result of these difficulties is the common practice of writing in completely fictional lot lines on the architectural plans.

Paradoxically, standards of open space are particularly high in the very housing projects which are progressively forced by outmoded zoning ordinances into the zoning districts permitting the greatest density and land coverage. Because of these standards, such large-scale developments do not, in Mr. Vladeck's words, "fill the permissible zoning envelopes."10 But surely that is not a wholesome condition. And the draftsman of a public housing or redevelopment project is engaged in a game to develop a modern functional design within the confines of the zoning regulations, often frustrated and blocked in situations where what he is trying to accomplish is more in harmony with the original purpose of the zoning provision in question, than is the specific application written into the language of the provision and no longer meaningful today (see, for example, Mr. Vladeck's description of the experiences of the architects for Lillian Wald houses). ${ }^{11}$

Consider by way of illustration the provisions in the New York City ordinance for set-backs above a certain height, which give New York's buildings their characteristic pyramid-like appearance. A high-rise housing project designed with straight walls, however slender, in order to be situated near a street requires a zoning district framed for a building having wide skirts and possibly three times its density.

Another characteristic problem under the New York City ordinance became the subject for one of the questions to housing authorities, as follows:

As to cities where the zoning ordinance requires off-street accessory parking, and the requirements are more strict in the less dense residential zoning districts: Has the parking requirement deterred otherwise desired zoning changes for housing projects?

In other words, under the New York City zoning regulations the parking requirements are directly tied to the area zoning requirements, and stiffer parking requirements follow automatically upon an improvement in standards of land coverage. The effect of this in one downtown project was to use up practically all the open land for parking facilities; although the parking facilities are fully used, many observers feel that under all the circumstances, it would have been wiser-i.e., better planning-to have used the space as green open land.

The parking problem just described seems to be limited to New York City.

${ }^{8}$ Large Scale Developments and One House Zoning Controls, 20 LAw \& ConTEMP. Pron. 255 (1955).

Id. at 256 .

${ }^{10} \mathrm{Id}$. at 257 .

${ }^{11}$ Id. at $258-26 \mathrm{r}$. 
Outside of New York, the question set forth above was met with comments that parking restrictions had caused no difficulty. Apparently many communities have the same parking requirements applicable to all zoning districts, even a requirement of one parking space per dwelling unit. A community without a roo per cent requirement reported that it had nevertheless provided roo per cent on-site parking for all the public housing projects. Possibly the question was not even understood outside of New York City.

Another case history on the relationship between zoning and housing design involves a city of moderate size where the housing authority had found it economical to build two-story row houses. The zoning ordinance was deliberately rewritten in 1944 to impose limitations on the public housing architects who, the planners feared, were depreciating or might depreciate neighborhood values by the design of their projects. Public housing design was put into a straitjacket. Under these limitations the maximum size of the permissible group is twelve attached houses, and there can be no more than four entrances to the housing units fronting on a street and no more than four entrances fronting on any court. The effect of these restrictions was to force a standard design in an $L$ or $U$ shape. The full text of the applicable provision is reproduced below in the footnote; ${ }^{12}$ it illustrates the extreme possibility in rigidity of zoning control over design. The projects designed under these regulations naturally all look alike, and it was the despair of the housing authority architects to be thus limited in their imagination and in the possibility of developing an improved design from the standpoint of either economy, utility or beauty. Within the past year the same authority has embarked on a program of multi-story housing for economic reasons, and is now running into "impossible zoning situations" from the standpoint of design.

It is hoped that the trend to more flexible zoning restrictions, somewhat on the analogy of performance codes which are replacing the old specific building codes, will end the present difficulties. Perhaps after forty years of experience with zoning we may fairly conclude, however, that zoning is at best not a satisfactory technique for fine control of design. Its rigidity impedes progress, and its uniformity of application-an indispensable constitutional requirement-is "too coarse a screen for fine planning requirements."13

12 "The group shall consist of not more than twelve apartments per floor, nor more than twelve single family dwellings. The front entrances of not more than four single family dwellings nor more than four apartments per floor shall face any street upon which the lot abuts, and no such entrance shall face a rear yard or rear court. All front entrances of such group shall abut a street, front yard, or front court; cxcept that a front entrance may abut a side yard if all of the household unit to which such entrance is appurtenant is located no nearer the street upon which the lot abuts than the rear elevation of any part of the group having a front entrance abutting a street, front yard, or front court. No rear or service entrance, unless located below the main floor, shall face a street, front yard, or front court. All courts shall be at least 8 inches wide for each foot of court depth; provided, no court abutting the front entrance of any houschold unit within the group shall be less than 40 feet in width, or less than 30 feet in depth. Inclosed courts are prohibited. The number of single family dwellings, or apartment units per floor, whose front entrances do not face a street, shall not exceed four in depth from any street abutting the property."

${ }^{13}$ This is Charles Ascher's felicitous phrase. Mr. Ascher, incidentally, has often remarked that 


\section{IV}

\section{Community Facilities}

Another possible source of difficulty is the zoning of residential areas without recognition of the need for community buildings and shops close by the new housing estate. Questions to elicit experiences in these matters were framed as follows:

What problems, if any, has your program experienced-

(a) because of zoning restrictions on community facilities, such as health centers, in or around housing projects?

(b) because of inadequate commercial zoning around housing projects, which creates a shortage of needed shopping facilities?

Only one authority, out of the many who were polled, reported difficulty in response to (a); the report on (b) was a resounding "None."

In this connection it is interesting to note that a city having a special zoning district for "comprehensively planned slum-clearance or low-rent housing projects sponsored by the United States government, non-profit corporations or by a municipal housing authority" permits within this district

any other accessory use incidental and essential to a slum clearance or low-rent housing development, such as community laundries, service buildings, offices and other community facilities.

No mention is made of shopping facilities, which would probably be excluded under ejusdem generis principles.

\section{$\mathrm{V}$}

\section{Admintstrative Questions}

\section{A. Frequency of Zoning Changes}

The questionnaire solicited full vital statistics on each of the housing authority's projects: name, project type, approximate year opened, number of dwelling units, number of stories, building type, present zoning district, whether rezoning required and if yes, out of what district.

In a surprisingly high percentage of cases rezoning has proved necessary. This would seem to indicate that something is wrong. One may fairly assume that under a well functioning zoning ordinance such frequency of change would not take place, and so it is of some interest to examine into the possible significance of the changes. Does the zoning ordinance chronically underzone for multiple housing, with the result that almost every time a housing project is contemplated it it necessary to change the residential district? Does the housing program ride roughshod over the zoning ordinance, causing spot zoning; is politics and not planning the final arbiter? Is the explanation simply that there is a formal requirement to rezone to a special zoning district reserved for housing and redevelopment projects?

the design of Radburn, a successful planned community in New Jersey with whose development he was associated, would not have been possible if conventionally zoned. 
Out of the more than twenty-five questionnaries returned, all of which, it will be recalled, were sent to large cities, four have clearly required no rezoning for their public housing projects. One of the four cited serious zoning difficulty, however, because of the zoning of vacant land for one and two-family dwellings, making unavailable to the authority a number of desirable sites. Another three cities also have not rezoned for housing, but in each case at least one project has been left in an area zoned for industry; it is customary, even under zoning ordinances that permit any higher use, to regularize the zoning once the project is undertaken, but in these three communities that has not been done. Moreover, these three cities have not been without their zoning difficulties; in one of them a proposed zoning change was killed by popular referendum. Finally, one city rezoned because of a special zoning district created for housing projects. So much for eight of the cities.

By far a majority of the cities reported that rezoning has taken place. Of some interest is an analysis of the zoning changes which have thus been made. The number of dwelling units involved in each zoning change was tabulated, and zoning changes were divided into two principal categories so far as applicable-namely, (a) changes from one and two-family residential districts to multiple family districts, and (b) changes from industrial or commercial districts to residential. When all the tabulations were in, approximately one-half of the changes involved each of these principal categories: (a) I2,519 units in 24 projects represented rezoning for multiple housing; (b) 13,468 units in $3^{6}$ projects represented rezoning for residential use. In other words, the necessity for zoning was evenly divided between the two.

As one would expect from this statistical record, the housing authorities mostly report fairly good cooperation from the organs of government that have it within their power to make zoning changes. "Utmost cooperation"; "high degree of harmony"; "excellent cooperation"; "effective cooperation." As one put it, "Regardless of zoning in effect we have always secured approval of a deviation therefrom to allow the construction of a project." Another related that the zoning regulations were "waived" for the benefit of the housing authority, following a wartime experience under which no compliance with local zoning was required because of federal involvement in the program. ${ }^{14}$

On the other extreme is an authority which frankly reports that it was given to understand that it was not to request any zoning changes regardless of its legal right to do so; it respected this advice.

\section{B. Power to Rezone for Housing}

It has been implicit in this entire discussion that housing and redevelopment projects are subject to local planning, zoning and building laws, and indeed, this is

${ }^{14}$ Local zoning regulations did not apply to housing constructed by the United States during the Second World War for war workers. Housing and Home Finance Agency, op. cit. supra note I, at xvi, and cases there cited. A similar situation obtained when the Federal Public Works Administration (PWA) was building public housing in the 'thirties. When title to such housing was transferred, compliance with local zoning abruptly became necessary. 
expressly provided by state law. ${ }^{15}$ Some jurisdictions declare more fully that: "In the planning and location of any housing project, an authority shall take into consideration the relationship of the project to any larger plan or long-range program for the development of the area in which it functions."16

But it would be hasty to conclude that the legal relation of housing to zoning is precisely the same as that of any private building project. The facility of zoning change described in the preceding section is grounded in a statutory grant of power to "plan or replan, zone or rezone" any part of the city in connection with any housing project. ${ }^{\mathbf{1 7}}$ This grant is part of the state enabling legislation which authorizes any city to enter into "cooperation agreements" with its housing authority and the Federal Government, and otherwise to aid the housing program in any way which may be necessary or convenient. ${ }^{18}$

A city's express power to rezone for housing was involved in the case of St. Stephen's Club v. Youngstown Metropolitan Housing Authority. ${ }^{10}$ The Club had sought to enjoin the housing authority's appropriation of its land for a federal housing project, partly on the ground that rezoning would be required. The zone was then an " $A$ " residence district, limited to single family dwellings (or, with leave, two-family dwellings). A change to a " $B$ " residence district would be necessary for this project, designed for 304 families in buildings housing from four to six families each. While affirming the lower court's judgment that compensation and possession should be postponed until the city had fulfilled its obligation to rezone, the Supreme Court of Ohio held that in view of the state enabling legislation and the cooperation agreement, which were standard, the necessity for rezoning would not invalidate the housing authority's appropriation proceeding.

A similar holding can be found in Blumenschein v. Housing Authority of Pittsburgh, ${ }^{20}$ where the Supreme Court of Pennsylvania upheld a housing project and the concomitant cooperation agreement over objections, inter alia, that the presently existing zoning restrictions would be interfered with. An illuminating comment is made in the dissenting opinion" ${ }^{21}$ that it was "manifestly unreasonable" to select as the site for the project "one of the highest class residential developments in the City" [of Pittsburgh]. The majority of the court reaffirmed, however, that site selection is not subject to judicial review in the absence of clearly arbitrary or capricious action.

${ }^{15}$ E.g., N.Y. Public Housing Law $\$ 155$ (1954); Pa. Stat. ANn. tit. 35, \$1556 (1937); Ill. Stat.

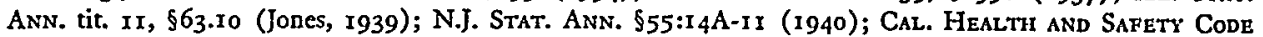
$\$ 34326$ (1952).

${ }_{10}^{16}$ See California, New Jersey, and Pennsylvania, supra note $\times 5$.

${ }^{17}$ E.g., Cat. Health and Safety Code $\$ 34513$ (a) (1952); N.Y. Public Housing Law \$99 (1954); PA. Stat. Ann. tit. 35, §1550(j) (3) (1937); Ill. Stat. AnN. tit. II, \$63.74(e) (Jones, r939); N.J. Stat. ANN. \$55:14B-4(d) (1940); OHo Rev. CoDE tit. 37, \$3735.52 (1953).

${ }^{18}$ E.g., in addition to state legislation referred to in note 17 , stupra (as a related subparagraph in cach case), N.H. Rev. LAws c. 169 , \$22 (1942); W. VA. CoDe of $1949 \$ 1409(62)$. Similar provisions appear in state urban redevelopment statutes, e.g., W. VA. SLUM Clearance aNd REDEvelopment Authority LAW §I6, W. VA. CODE OF I949 \$I409(III) (I953 Cum. Supp.).

${ }^{10}$ r6o Ohio St. 194, 115 N.E.2d 385 (r953).

${ }^{20} 379$ Pa. 566, 109 A.2d 33 I (r954).

21 I09 A.2d at $34 \mathrm{I}$. 
In Borek v. Golder, 22 a New York case, the court relied on the express power "to ... rezone" to defeat a taxpayer's action in so far as it challenged the right of the city of Utica to select a predominantly open site zoned for single-family dwellings as the site for a multiple housing project. The court held there was no violation of the local zoning law. ${ }^{23}$

C. Frustration of Zoning Change Agreed to by City Legislative Body

I. Protest by Affected Property Owners. The model act prepared by the Department of Commerce confers upon 20 per cent of the affected property owners the right to protest against any change in an existing zoning ordinance, whereupon the requisite vote to pass the amendment is increased to three-quarters. This provision was widely adopted, often modified in one or more particulars. Thus, in one jurisdiction a protest is effective if joined in by so per cent, in another, if joined in by 40 per cent. There is also wide variation in the vote required to override the protest. $^{24}$

Legally, how does this right of protest fare in the case of public housing projects, and in particular, in the case of projects which the city is committed to carry forward because of a formal cooperation agreement with the Federal Government, for example?. It is now well established that the city is bound to respect this agreement. ${ }^{2{ }^{a}}$ The cooperation agreement erects into a duty to rezone, the power to rezone conferred by the state laws described in the preceding section.

First let us examine what experience the housing authorities have had with these protests to date.

Latent possibilities of head-on conflict between this right of protest and the housing program's right of way emerged squarely in a recent New York case, Rabasco v. Town of Greenburgh. ${ }^{25}$ The intermediate appellate court of the state held invalid a purported amendment of the zoning ordinance for a public housing project, because the amendment failed to obtain a three-quarters vote of the entire town board after there had been a written protest by 20 per cent of the affected property owners, residents of the areas proposed to be rezoned or the areas adjacent or opposite. Two members of the court dissented, taking the view that only a majority vote was required. The dissenting judges argued as a matter of statutory construction that in the absence of specific language stating that the power of a majority of the local legislative body to approve a plan for a housing project shall not be sufficient if 20 per cent of the affected property owners object, such a specific limitation cannot be imposed on the broad housing powers conferred by the state Constitution and the Public Housing Law. "It would appear," they contended, ${ }^{26}$ "that the Legislature 2274 N.Y.S.2d 675 (Sup. Ct. 1947).

${ }^{23}$ The court's opinion also noted (at p. 696): "The acute need of housing and the trend toward multiple units is so generally accepted that a change of zoning to permit such developments is not sufficient to establish illegality." Cf. note 5 supra.

${ }^{24}$ Consult Housing and Home Finance Agency, op. cit. supra note I.

${ }^{262}$ Housing Authority v. City of Los Angeles, 38 Cal.2d 853, 243 P.2d 515 (1952), infra note 33.

${ }^{25}{ }_{137}$ N.Y.S.2d 802 (2d Dep't 1955).

${ }^{20}$ Id. at 806 . 
has substituted the qualified approval or disapproval by a planning board for the protest of twenty per cent of the owners as the basis for requiring more than a majority vote...." In this case the approval of the planning board was unqualified, except in so far as it raised the question of the adequacy of the vote on the zoning amendment.

As an alternative to the protest provision, at least one state requires that no zoning change is effective without the written consent of two-thirds of the affected property owners. ${ }^{27}$ Replies to the questionnaire which was circulated among housing authorities disclosed that this requirement had been responsible in one city alone for preventing two housing projects proposed to be built on vacant land and requiring a change of zoning district from " $A$ " to " $C$."

So the score now stands on the experience of housing authorities with the protest and consent provisions in zoning ordinances-a limited experience, all of it unfavorable. It is significant that such provisions have in some contexts been held inoperative by the courts in the public interest. The United States Supreme Court in a ringing opinion struck down a consent provision which was preventing the construction of a spacious old people's home in a single family residential district: "They [the adjacent property owners] are not bound by any official duty, but are free to withhold consent for selfish reasons or arbitrarily. ... The delegation of power so attempted is repugnant to the due process clause of the Fourteenth Amendment." ${ }^{28}$ And in New York, in holding unconstitutional under both the state and federal constitutions a provision requiring the consent of 80 per cent of the adjacent property owners to the erection of a school building in a residential district, the highest state court said: “... we are not dealing with billboards or garages or other offensive uses in connection with which consent provisions may be proper. . . "28a How ironic that public housing has so far had the fate of the offensive uses rather than the proper uses, and also how inconsistent with the series of constitutional tests certifying to its public purposes. Subjection of the public housing program to the hazards of the protest and consent provisions of local zoning regulations is anomalous and, it is to be hoped, short-lived.

2. Referendum. In some jurisdictions a zoning change can be defeated by a popular referendum. There was a striking example in 1953 of how this could frustrate a zoning change needed for a housing project. As reported in a reply to the questionnaire, the referendum was held after the City Council had changed the zoning of a proposed housing site. "Zoning change was defeated, thus preventing construction of project."

On the analogy of the reasoning that provisions giving a per cent of the affected property owners a right of protest have no application to housing and redevelopment projects, it is arguable that referendum privileges also are inapplicable. In

${ }^{27}$ Minnesota. South Dakota authorizes a requirement for 60 per cent consent in addition to making zoning amendments subject to referendum and protest.

${ }^{28}$ Washington ex rel. Seattle Title Trust Co. v. Roberge, 278 U.S. 116,122 (1928).

${ }^{28 a}$ Concordia Collegiate Institute v. Miller, 301 N.Y. 189, 195, 93 N.E.2d 632, 635 (1950). 
fact this has been squarely adjudicated and so held in California. In Lockhart $v$. City of Bakersfield, ${ }^{29}$ the intermediate appellate court of California took the view that the referendum provisions were inapposite and could not abridge the power to zone and rezone for housing projects, which power had independent derivation from state law. ${ }^{30}$ The court was aided in this conclusion by a provision in the housing authorities law that no law concerning the acquisition of property by other public bodies is applicable to housing authorities unless the legislature so states. ${ }^{31}$

The facts of the Lockhart case were briefly as follows: In accordance with the provisions of a cooperation agreement, the city of Bakersfield rezoned an area from a one-family to a two-family residence district in order to make feasible a duplex public housing development. Thereafter a referendum petition to submit this rezoning ordinance to the voters was filed. The city, nevertheless, went ahead and expressly approved the site for the project, in a resolution to take effect immediately. At that time the election date was set for some three months later. This suit was then brought, unsuccessfully, to enjoin the allegedly unauthorized rezoning. ${ }^{32}$

3. Successor Public Body or Different City Department. Under recent case law it would seem that there is no longer room for doubt that a successor city legislative body is bound by the action of its predecessor in entering into a cooperation agreement for the planning and construction of public housing projects. ${ }^{33}$ It will be recalled that the cooperation agreement specifically commits the city to plan and replan, zone and rezone, as may be necessary and convenient, both the housing project site and the surrounding area. But far more difficult than the problem of binding a successor council is the problem that the council may not be the repository of power to make zoning changes for the community.

In addition to its dependence on another agency for the making of necessary zoning changes, the city council or other body which has authorized execution of the cooperation agreement may find it then has to satisfy the planning commission as to conformity with the master plan. In Drake v. City of Los Angeles, ${ }^{34}$ a taxpayer sought to enjoin the progress of the city's public housing program on the grounds, inter alia, that the matter of the cooperation agreement had not first been submitted to the City Planning Commission for approval and recommendation in relation to the master plan, and that none of the sites had been approved by the City Planning

${ }^{20} 267$ P.2d 87x (1954).

${ }^{30}$ The court leaned heavily on the rationale of Housing Authority v. City of Los Angeles, 38 Cal.2d 853, 243 P.2d 515 (1952), infra note 33 .

${ }^{31}$ Cal. Health AND Safety CODE $\$ 34320$ (1952).

${ }^{32} \mathrm{Cf}$. State ex rel. Great Falls Housing Authority v. City of Great Falls, iro Mont. 3r8, roo P.2d 915 (1940), raising an argumentative point involving a referendum on zoning. There a mandamus writ issued directing the city to comply with its agreement to rezone certain blocks and change the street pattern. Among other things, the court considered whether the referendum law was abridged by the provisions of the cooperation agreement, and concluded that it was not.

${ }^{33}$ Housing Authority v. City of Los Angeles, 38 Cal.2d 853, 243 P.2d 5I5 (I952), cert. denied, 344 U.S. 836 (1952). Cf. State ex rel. Helena Housing Authority v. City Council of City of Helena, I25 Mont. 592, 242 P.2d 250 (1952).

${ }^{34}{ }_{38}$ Cal.2d 872, 243 P.2d 525 (1952). 
Commission. An injunction was denied on the basis of a considered analysis of the related statutes which concluded that the requirements in question were not a condition precedent to the action of the council. Incidentally, the Supreme Court of California pointed out that at the time the housing project was before the City Council for general authority to execute a cooperation agreement, specific plans for the project were not yet formulated; submission to the planning commission was scheduled to come later.

Whether or not rezoning is required at the time the project is planned and constructed, zoning problems may lie in wait for the housing authority in connection with the zoning of the surrounding area. Here again there is an acute question how firmly the city agency executing or authorizing the execution of the cooperation agreement can control the local body having jurisdiction over variances, and over zoning amendments. New York State provides an excellent case in point. A provision in the Public Housing Law expressly requires as a condition precedent to receiving a state loan for a project that "the municipality ... has enacted or will enact zoning regulations or other restrictions adequately protecting the area or areas ... against future uses likely to depreciate unduly the value of such project."35 The State Housing Commissioner conscientiously exacts such conditions from local housing authorities, and negotiations on these points are detailed, usually call for compliance within six months, and become a part of the loan agreement. The Commissioner can withhold financial aid in the event of a breach.

Now, in New York City, for example, it is the Board of Estimate which signs the loan agreement with the State, and the Board of Standards and Appeals which has the authority to grant zoning changes. There appears to be some misgiving on the part of the city as to the extent to which it can or should bind the Board of Standards and Appeals, apparently in perpetuity, not to grant any zoning variances inconsistent with the Board of Estimate's agreement with the State Housing Commissioner. Apparently inspired by the office of the State Commissioner, a provision was added to the Public Housing Law in I954, partly clarifying this situation, to the effect that all zoning regulations or other restrictions enacted by the municipality to protect adequately the area of a project must be maintained thereafter without variance, unless at least ten days' prior written notice is given to the housing authority and the government providing financial assistance of a public hearing on the proposed change. ${ }^{36}$

\section{Concluston and SUMmary}

r. Zoning has fulfilled its promise in protecting the area of a housing project against future depreciating uses of the surrounding area.

2. Zoning mirrors the lack of comprehensive planning in the community. This has had consequences in the common practice of spot zoning, the common under-

${ }^{35}$ N.Y. Public Housing Law $\$ 7 \mathrm{I}(\mathrm{I})$ (b) (Cum. Supp. 1954).

${ }^{30}$ Sec. 155 , as amended, L. 1954 , c. 130. 
zoning for multi-family housing, and the occasional perversion of zoning to checkmate public housing.

3. Zoning has proved obsolete in many communities from the standpoint of architectural design of large-scale housing projects, and a reform movement is under way to correct this. Zoning has shackled public housing design in other ways as well and has run up costs.

4. Zoning has occasionally thwarted the establishment of needed community facilities in close proximity to a housing estate.

5. Zoning has, over-all, a good record of cooperation with housing on the administrative level. There are germs of conflict, which erupt from time to time, between the traditional repositories of local zoning policy and the overriding state public policy to authorize zoning changes for the necessity and convenience of public housing projects. 